\title{
Synthesis, Characterization and Cytotoxicity Evaluation of New Biimidazole Palladium(II) Complexes with Thioureas
}

\author{
Silmar José Spinardi Franchi, ${ }^{1,}{ }^{*}$ Rodrigo Alves de Souza, ${ }^{2}$ \\ Antonio Eduardo Mauro, ${ }^{2}$ Iracilda Zeppone Carlos, ${ }^{3}$ Livia Carolina \\ de Abreu Ribeiro, ${ }^{3}$ Fillipe Vieira Rocha ${ }^{4}$ and Adelino Viera de Godoy-Netto ${ }^{2}$ \\ ${ }^{1}$ UFSC - Universidade Federal de Santa Catarina, Departamento de Ciências Exatas e Educação, \\ 89036-256, Blumenau, SC, Brazil. \\ ${ }^{2}$ UNESP - Sao Paulo State Univ, Instituto de Química de Araraquara, C.P. 355, 14800-900, Araraquara, SP, Brazil. \\ ${ }^{3}$ UNESP - Sao Paulo State Univ, Faculdade de Ciências Farmacêuticas, 14801-902, Araraquara, SP, Brazil. \\ ${ }^{4}$ UFSCar - Universidade Federal de São Carlos, Departamento de Química, 13565-905, São Carlos, SP, Brazil. \\ *Corresponding author: E-mail: silmar.franchi@ufsc.br \\ Tel: + 554837213339
}

Received: 19-12-2017

\begin{abstract}
The reactions between $\left[\mathrm{PdCl}_{2}\left(\mathrm{tmbiimH}_{2}\right)\right] \cdot \mathrm{H}_{2} \mathrm{O}$ (1) $\left\{\mathrm{tmbiimH}_{2}=2,2^{\prime}\right.$-bis(4,5-dimethylimidazole $\left.)\right\}$ and thiourea (tu), $N$-methylthiourea (mtu), $N$-phenylthiourea (ptu), $N, N^{\prime}$-dimethylthiourea (dmtu) or $N, N^{\prime}$-diphenylthiourea (dptu) in the 1:2 molar ratio resulted in the compounds $\left[\mathrm{PdL}_{2}\left(\mathrm{tmbiimH}_{2}\right)\right] \mathrm{Cl}_{2} \cdot \mathrm{nH}_{2} \mathrm{O}\{\mathrm{L}=\mathrm{tu}(2), \mathrm{mtu}(3)$, ptu (4), dmtu (5) and dptu (6)\}, which were characterized by elemental analyses, infrared (IR), and ${ }^{1} \mathrm{H}$ NMR spectroscopies and conductivity measurements. The IR spectra of 1-6 were consistent with the presence of chelating tmbimH $\mathrm{H}_{2}$ ligand. All compounds and cisplatin were tested in vitro by MTT assay for their cytotoxicity against three murine cancer cell lines: mammary adenocarcinoma (LM3), lung adenocarcinoma (LP07) and mouse fibroblast (L929) cells. Relating the series of compounds to their biological activities we found compound $\mathbf{6}$ as the most promising of them.
\end{abstract}

Keyword: Palladium(II); 2,2'-bis(4,5-dimethylimidazole); Thioureas; Cytotoxicity; Cancer

\section{Introduction}

Cisplatin is one of the most widely used and most effective chemotherapeutic agent for treatment of patients with epithelial malignancies such as lung, head, neck, ovarian, bladder and testicular cancer. ${ }^{1}$ Despite its resounding success, cisplatin suffers from two major drawbacks which are severe side effects and intrinsic and acquired drug resistance. ${ }^{2}$ Much current research work is aimed at the discovery of new complexes bearing platinum or other metals which may display a wide spectrum of activity and reduced toxicities, thus leading to improvements in the effectiveness of cancer chemotherapy regimens. ${ }^{3-4}$ In this context, numerous cisplatin analogues have been synthesized by modifying the nature of the leaving groups and the carrier ligands. ${ }^{5}$ Nevertheless, such derivatives generally have shown similar DNA-binding modes which often result in a similar spectrum of activity. Therefore, one conceivable strategy to achieve a spectrum of activity distinct to that of cisplatin involves the development of agents capable of producing cytotoxicity through new types of DNA interaction. ${ }^{6}$

It is well-established that metal-based molecules are able to interact non-covalently with DNA by means of a non-specific (mainly electrostatic) binding along the DNA exterior, a specific groove binding and intercalation. ${ }^{7}$ Particularly, much effort has been directed towards the design of square-planar complexes of the type $\left[\mathrm{M}(\mathrm{N}-\mathrm{N}) \mathrm{L}_{2}\right]^{2+}(\mathrm{M}$ $=\mathrm{Pd}, \mathrm{Pt})$ incorporating chelating planar aromatic heterocycles with extended $\pi$-systems $(\mathrm{N}-\mathrm{N})$ such as $2,2^{\prime}$-bipyri- 
dine, 1,10-phenanthroline, and kinetically less labile ligands (L), e.g. thiourea ligands. ${ }^{8-10}$ These compounds are relatively inert toward possible competitive covalent interactions and display the suitable shape for DNA intercalation.

Specifically, 2,2'-biimidazoles are $\mathrm{N}, \mathrm{N}$-donor ligands which can be used to obtain new metal complexes able to interact non-covalently to DNA as they can act as neutral bidentate ligands depending upon its protonation state. ${ }^{11}$ Metal-based complexes containing neutral chelating 2,2'-biimidazole-type ligands have attracted considerable interest due to their externally-directed pair of $\mathrm{N}-\mathrm{H}$ groups which are frequently involved in hydrogen bonding with solvent molecules and counterions ${ }^{12}$. Indumathy and co-workers ${ }^{13}$ reported that the complexes $\left[\mathrm{Co}(\mathrm{N}-\mathrm{N})_{2}\left(\mathrm{H}_{2} \text { biim }\right)\right]^{3+}\left(\mathrm{N}-\mathrm{N}=2,2^{\prime}\right.$-bipyridine, 1,10-phenanthroline) interact with DNA through the groove via hydrogen bonding due to presence of - $\mathrm{NH}$ in the ancillary ligand 2,2'-biimidazole.

Inspired by the ability of 4,5-dialkylimidazoles in extracting metal complexes into hydrophobic or hydrophilic solvents, ${ }^{14}$ Stringfield and co-workers ${ }^{15}$ have employed 2,2'-bis(4,5-dimethylimidazole), $\operatorname{tmbiimH}_{2}$, as a carrier ligand in order to facilitate transport of metal complexes across cell membranes. We assumed that the introduction of 2,2'-bis(4,5-dimethylimidazole) in the structure of $\mathrm{Pd}(\mathrm{II})$ complexes may improve the membrane penetration by increasing their lipid solubility and, consequently, resulting in an enhancement of the cytotoxicity.

Motivated by the aforementioned findings, and as a part of our continuing research program in the field of coordination and biological chemistry of $\mathrm{Pd}(\mathrm{II})$ complexes, ${ }^{16-21}$ we present herein the synthesis, characterization and cytotoxic evaluation of the compounds $\left[\mathrm{PdL}_{2}(\mathrm{tm}-\right.$ biimH $\left.\left.\mathrm{H}_{2}\right)\right] \mathrm{Cl}_{2} \cdot \mathrm{nH}_{2} \mathrm{O}$, where L is thiourea (2), $\mathrm{N}$-methylthiourea (3), $N$-phenylthiourea (4), $N, N^{\prime}$-dimethylthiourea (5), $N, N^{\prime}$-diphenylthiourea (6); $\mathrm{n}=3-5 ; \mathrm{tmbiimH}_{2}$ is 2,2'-bis(4,5-dimethylimidazole).

\section{Experimental}

\section{1. Materials and Measurements}

The syntheses were performed at room temperature. Commercial reagents and solvents were employed without further purification. The starting material $\mathrm{Na}_{2}\left[\mathrm{PdCl}_{4}\right]$ was prepared as previously described. ${ }^{22}$

Elemental analyses $(\mathrm{C}, \mathrm{N}$ and $\mathrm{H})$ were performed on an EA1110-CHNS-O microanalyzer from CE-Instruments. Infrared spectra were recorded on a Nicolet Impact 400 spectrophotometer in the spectral range $4000-$ $400 \mathrm{~cm}^{-1}$ ( $\mathrm{KBr}$ pellets). Conductivities were measured with a Digimed-DM-31 conductimeter using $1 \times 10^{-3}$ mol L ${ }^{-1}$ solutions in methanol. ${ }^{1} \mathrm{H}$ NMR spectra were obtained as DMSO- $d_{6}$ solutions, on a Varian INOVA 500 spectrometer.

\section{2. Preparation of the Coordination Compounds}

\section{Synthesis of $\left[\mathrm{PdCl}_{2}\left(\mathrm{tmbiimH}_{2}\right)\right] \cdot \mathrm{H}_{\mathbf{2}} \mathrm{O}(\mathbf{1})$}

Briefly, the compound $\mathbf{1}$ was prepared similarly as described for $\left[\mathrm{PdCl}_{2}\left(\mathrm{biimH}_{2}\right)\right]$ (Casas et al., 2003). ${ }^{23}$ To 20.0 $\mathrm{mL}$ of a deep orange solution of $\mathrm{Na}_{2}\left[\mathrm{PdCl}_{4}\right](200.0 \mathrm{mg}$, $0.68 \mathrm{mmol})$ was added a suspension of tmbiimH $\mathrm{H}_{2}(133.0$ $\mathrm{mg}, 0.70 \mathrm{mmol})$ in methanol $(20.0 \mathrm{~mL})$, followed by the addition of $1.0 \mathrm{~mL} 37 \% \mathrm{HCl}$ solution. The reaction mixture was stirred for $2 \mathrm{~h}$. The resulting red-brownish solution was concentrated and the obtained microcrystalline yellow solid was isolated and washed with cold water and ethanol, and dried under vacuum. The yield was $79 \%$. Anal. Calc. for $\mathrm{C}_{10} \mathrm{~N}_{4} \mathrm{H}_{16} \mathrm{Cl}_{2} \mathrm{OPd}\left(\mathbf{1} \cdot \mathrm{H}_{2} \mathrm{O}\right)$ : C, 31.21; H, 4.11; N, 14.49. Found: C, 31.00; H, 4.47; N, 14.32. IR (KBr, $\left.\mathrm{cm}^{-1}\right): 3488,3230,2926,1650,1594,1379,781$.

\section{Synthesis of $\left[\mathrm{Pd}(\mathrm{tu})_{2}\left(\mathrm{tmbiimH} \mathrm{H}_{2}\right)\right] \mathrm{Cl}_{2} \cdot \mathbf{3} \mathrm{H}_{2} \mathrm{O}$ (2)}

To a yellow suspension of $\mathbf{1}(60.0 \mathrm{mg}, 0.163 \mathrm{mmol})$ in 20.0 $\mathrm{mL}$ of $\mathrm{MeOH}$, thiourea $(24.8 \mathrm{mg}, 0.33 \mathrm{mmol})$ in $10.0 \mathrm{~mL}$ of methanol was added slowly, affording a red brownish solution. The resulting solution was stirred for $2 \mathrm{~h}$ and then filtered to eliminate some impurities. The solution was evaporated to dryness and cooled diethyl ether (10.0 $\mathrm{mL}$ ) added to the residue. The red brownish solid was filtered, washed with diethyl ether $(5.0 \mathrm{~mL})$ and dried under vacuum. The yield was $80 \%$. Anal. Calc. for $\mathrm{C}_{12} \mathrm{~N}_{8} \mathrm{H}_{28} \mathrm{C}$ $\mathrm{l}_{2} \mathrm{O}_{3} \mathrm{~S}_{2} \mathrm{Pd}\left(\mathbf{2} \cdot 2 \mathrm{H}_{2} \mathrm{O}\right): \mathrm{C}, 25.11 ; \mathrm{H}, 4.87 ; \mathrm{N}, 19.51$. Found: C, 24.84; H, 4.43; N, 19.68. $\Lambda$ : $205 \Omega^{-1} \mathrm{~cm}^{-2} \mathrm{~mol}^{-1}$. IR (KBr, $\mathrm{cm}^{-1}$ ): 3379-2420, 1660, 1629, 1504, 709 .

\section{Synthesis of $\left[\mathrm{Pd}(\mathrm{mtu})_{2}\left(\mathrm{tmbiimH}_{2}\right)\right] \mathrm{Cl}_{2} \cdot \mathbf{4} \mathrm{H}_{2} \mathrm{O}(3)$}

Prepared similarly to 2 from the reaction between compound $1(60.0 \mathrm{mg}, 0.163 \mathrm{mmol})$ and $N$-methylthiourea $(29.4$ $\mathrm{mg}, 0.33 \mathrm{mmol})$. The yield was $80 \%$. Anal. Calc. for $\mathrm{C}_{14} \mathrm{~N}_{8} \mathrm{H}_{34} \mathrm{Cl}_{2} \mathrm{O}_{4} \mathrm{~S} 2 \mathrm{Pd}\left(3 \cdot 4 \mathrm{H}_{2} \mathrm{O}\right): \mathrm{C}, 27.11 ; \mathrm{H}, 5.46 ; \mathrm{N}$, 18.13. Found: C, 26.72; H, 5.32; N, 17.84. $\Lambda_{\mathrm{M}}: 201 \Omega^{-1} \mathrm{~cm}^{-2}$ $\mathrm{mol}^{-1}$. IR $\left(\mathrm{KBr}, \mathrm{cm}^{-1}\right): 3354,2490,1650,1631,1576,1489$, 767.

\section{Synthesis of $\left[\mathrm{Pd}(\mathrm{ptu})_{2}\left(\mathrm{tmbiimH}_{2}\right)\right] \mathrm{Cl}_{2} \cdot \mathbf{5} \mathrm{H}_{2} \mathrm{O}(4)$}

Prepared similarly to 2 from the reaction between compound $1(60.0 \mathrm{mg}, 0.163 \mathrm{mmol})$ and $N$-phenylthiourea (49.6 mg, $0.33 \mathrm{mmol}$ ). The yield was $75 \%$. Anal. Calc. for $\mathrm{C}_{24} \mathrm{~N}_{8} \mathrm{H}_{40} \mathrm{Cl}_{2} \mathrm{O}_{5} \mathrm{~S}_{2} \mathrm{Pd}\left(4 \cdot 5 \mathrm{H}_{2} \mathrm{O}\right)$ : C, 37.80; H, 5.33; N, 14.71 . Found: C, 37.62; H, 5.51; N, 14.43. ${ }_{\Lambda \mathrm{M}}: 194 \Omega^{-1} \mathrm{~cm}^{-2} \mathrm{~mol}^{-1}$. IR $\left(\mathrm{KBr}, \mathrm{cm}^{-1}\right): 3499,2487,1648,1620,1463,1402,751$.

Synthesis of $\left[\mathrm{Pd}(\mathrm{dmtu})_{2}\left(\mathrm{tmbiimH}_{\mathbf{2}}\right)\right] \mathrm{Cl}_{\mathbf{2}} \cdot \mathbf{5} \mathbf{H}_{\mathbf{2}} \mathrm{O}(5)$

Prepared similarly to 2 from the reaction between compound $1(60.0 \mathrm{mg}, 0.163 \mathrm{mmol})$ and $N, N^{\prime}$-methylthiourea (34.0 $\mathrm{mg}, 0.33 \mathrm{mmol}$ ). The yield was $69 \%$. Anal. Calc. for $\mathrm{C}_{16} \mathrm{~N}_{8} \mathrm{H}_{42} \mathrm{Cl}_{2} \mathrm{O}_{5} \mathrm{~S}_{2} \mathrm{Pd}\left(5 \cdot 5 \mathrm{H}_{2} \mathrm{O}\right): \mathrm{C}, 28.91 ; \mathrm{H}, 6.08 ; \mathrm{N}, 16.78$. Found: C, 28.64; H, 5.79; N, 17.01. $\Lambda \mathrm{M}: 199 \Omega^{-1} \mathrm{~cm}^{-2} \mathrm{~mol}^{-1}$. IR $\left(\mathrm{KBr}, \mathrm{cm}^{-1}\right): 3471,2600,1620,1593,1517,1377,718$. 
Synthesis of $\left[\mathrm{Pd}(\mathrm{dptu})_{2}\left(\mathrm{tmbiimH}_{2}\right)\right] \mathrm{Cl}_{2} \cdot 3 \mathrm{H}_{2} \mathrm{O}(6)$

Prepared similarly to 2 from the reaction between compound $1(60.0 \mathrm{mg}, 0.163 \mathrm{mmol})$ and $N, N^{\prime}$-diphenylthiourea $(74.4 \mathrm{mg}, 0.33 \mathrm{mmol})$. The yield was $65 \%$. Anal. Calc. for $\mathrm{C}_{36} \mathrm{~N}_{8} \mathrm{H}_{44} \mathrm{Cl}_{2} \mathrm{O}_{3} \mathrm{~S}_{2} \mathrm{Pd}\left(6 \cdot 3 \mathrm{H}_{2} \mathrm{O}\right)$ : C, 53.44; $\mathrm{H}, 5.92$; $\mathrm{N}, 10.11$. Found: C, 53.10; H, 5.74; N, 9.78. ${ }_{\Lambda \mathrm{M}}: 192 \Omega^{-1}$ $\mathrm{cm}^{-2} \mathrm{~mol}^{-1}$. IR $\left(\mathrm{KBr}, \mathrm{cm}^{-1}\right): 3407,2500,1595,1510,1267$, $1195,729,510$.

\section{3 Cytotoxicity Activity}

\section{3. 1. Cells}

Mouse fibroblast cells (L929) were propagated in Eagle's Minimum Essential Medium, MEM, from Institute Adolfo Lutz, Sao Paulo, Brazil, supplemented with $80 \mu \mathrm{g} \mathrm{mL}$ of gentamicin and $7.5 \% \mathrm{v} / \mathrm{v}$ fetal bovine serum (FBS). $\mathrm{Mu}-$ rine mammary adenocarcinoma (LM3) and lung adenocarcinoma (LP07) cells were maintained in MEM, supplemented with $10 \%$ heat-inactivated FBS, $2 \mathrm{mmol} \mathrm{L}^{-1}$ of $L$-glutamine, and $80 \mu \mathrm{g} \mathrm{mL}^{-1}$ of gentamicin, defined as complete medium, in plastic flasks (Corning) at $37^{\circ} \mathrm{C}$ in a humidified $5 \% \mathrm{CO}_{2}$ atmosphere. Passages were made by trypsinization of confluent monolayers (0.25\% trypsin and $0.02 \%$ EDTA in $\mathrm{Ca}^{2+}$ $\mathrm{Mg}^{2+}$ free phosphate-buffered saline). The cells number was counted by the Trypan blue dye exclusion method.

\section{3. 2. Compounds}

Test solutions of the compounds $\left(1000 \mu \mathrm{mol} \mathrm{L}{ }^{-1}\right)$ were freshly prepared by dissolving the substances in 50 $\mu \mathrm{L}$ of DMSO and completing with $4950 \mu \mathrm{L}$ of the culture medium. Afterwards, the tested compounds were diluted in a culture medium to reach the desired concentrations ranging from 10 to $300 \mu \mathrm{mol} \mathrm{L}^{-1}$. The DMSO solvent did not reveal any cytotoxic activity in the tested concentrations. Cisplatin (commercial compound from Sigma) was employed as the standard antitumor drug.

\section{3. 3. MTT Assay}

For the cytotoxicity evaluation, 200.0 ML samples of L929, LM3 and LP07 cells $\left(5 \times 10^{4}\right.$ cell $\mathrm{mL}^{-1}$, adjusted in
MEM) were added to each well of a 96-well tissue culture plate and then preincubated in the absence of the compounds for $24 \mathrm{~h}$ to allow adaptation of the cells prior to the addition of the test agents. Afterwards, the supernatants were removed and 200.0 ML solutions of the compounds in concentrations ranging from 10 to $300 \mu \mathrm{mol} \mathrm{L}^{-1}$ or 200.0 ML of MEM-Complete as cell control of viability was added to each well. The effects of the compounds towards the cells were determined $24 \mathrm{~h}$ after the culture incubation. After that, the supernatants were removed and $100.0 \mu \mathrm{L}$ solutions of [3-(4,5-dimethylthiazol-2-yl)-2,5-diphenyltetrazolium bromide], MTT, were added in each well containing the samples. ${ }^{24}$ The MTT assay was performed and the plates were incubated for $3 \mathrm{~h}$. Then, the absorbances were measured and the cytotoxic midpoint value, i.e. the concentration of the chemical agent needed to reduce the spectrophotometric absorbance to $50 \%$, was determined by linear regression analysis with $95 \%$ of confidence limits. The $\mathrm{IC}_{50}$ was defined as the medium of three independent experiments through the equation of graphic line obtained (Microcal Origin $8.0^{\mathrm{TM}}$ ). Triplicates tests were performed for each concentration of each compound.

\section{Results and Discussion}

The precursor $\mathrm{Na}_{2}\left[\mathrm{PdCl}_{4}\right]$ reacts with 2,2'-bis(4,5-dimethylimidazole) in acidified methanol, to afford [Pd$\left.\mathrm{Cl}_{2}\left(\mathrm{tmbiimH}_{2}\right)\right] \cdot \mathrm{H}_{2} \mathrm{O}$ (1). Compounds $\left[\mathrm{Pd}(\mathrm{tu})_{2}(\mathrm{tm}-\right.$ biimH $\left.\left.\mathrm{H}_{2}\right)\right] \mathrm{Cl}_{2} \cdot 3 \mathrm{H}_{2} \mathrm{O}(2)$, $\left[\mathrm{Pd}(\mathrm{mtu})_{2}\left(\mathrm{tmbiimH}_{2}\right)\right] \mathrm{Cl}_{2} \cdot 4 \mathrm{H}_{2} \mathrm{O}$ (3), $\left[\mathrm{Pd}(\mathrm{ptu})_{2}\left(\mathrm{tmbiimH} \mathrm{H}_{2}\right)\right] \mathrm{Cl}_{2} \cdot 5 \mathrm{H}_{2} \mathrm{O}(4),\left[\mathrm{Pd}(\mathrm{dmtu})_{2}(\mathrm{tm}-\right.$ biimH $\left.\left.\mathrm{H}_{2}\right)\right] \mathrm{Cl}_{2} \cdot 5 \mathrm{H}_{2} \mathrm{O}(5)$, and $\left[\mathrm{Pd}(\mathrm{dptu})_{2}\left(\mathrm{tmbiimH}_{2}\right)\right] \mathrm{Cl}_{2}$. $3 \mathrm{H}_{2} \mathrm{O}(6)$ are readily obtained by reacting 1 with thiourea, and $N$-methylthiourea, $N$-phenylthiourea, $N, N$ '-dimethylthiourea and $N, N^{\prime}$-diphenylthiourea, respectively. The six compounds presented here are in square planar molecular geometry surrounding of $\mathrm{Pd}(\mathrm{II})$ center, according to spectroscopic results and in analogy with literature. ${ }^{8,10} \mathrm{~A}$ representation of the strategy employed for to obtain the complexes is pointed in Scheme 1.

The syntheses were carried out at room temperature under constant magnetic stirring. The complexes are

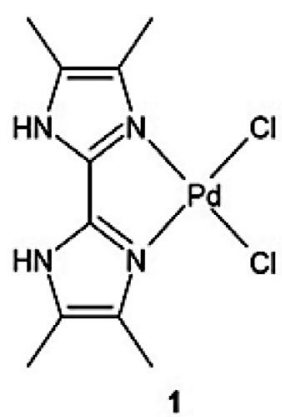

1

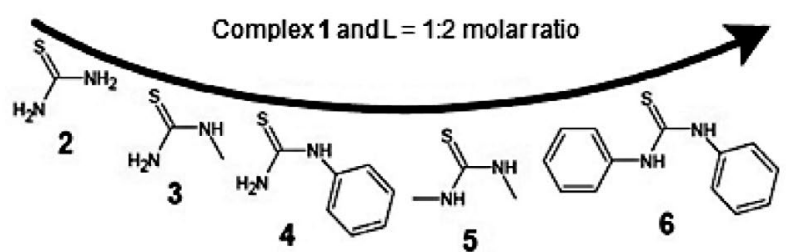

5

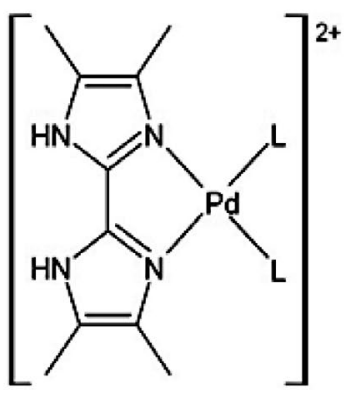

Scheme 1: General representation for the synthesis of the complexes (water of hydration is omitted).

Franchi et al.: Synthesis, Characterization and Cytotoxicity Evaluation ... 
Table 1. Analytical and physicochemical data for the compounds 1-6.

\begin{tabular}{|c|c|c|c|c|c|c|c|c|}
\hline \multirow[t]{2}{*}{ Complex } & \multirow{2}{*}{$\begin{array}{c}\Lambda_{\mathrm{M}} \\
\left(\Omega^{-1} \mathrm{~cm}^{-2} \mathrm{~mol}^{-1}\right)\end{array}$} & \multirow{2}{*}{$\begin{array}{c}\text { M. p. } \\
\left({ }^{\circ} \mathrm{C}\right)\end{array}$} & \multicolumn{2}{|c|}{ Carbon (\%) } & \multicolumn{2}{|c|}{ Nitrogen (\%) } & \multicolumn{2}{|c|}{ Hydrogen (\%) } \\
\hline & & & Found & Calc. & Found & Calc. & Found & Calc. \\
\hline $\mathrm{C}_{10} \mathrm{~N}_{4} \mathrm{H}_{16} \mathrm{Cl}_{2} \mathrm{OPd}\left(\mathbf{1} \cdot \mathrm{H}_{2} \mathrm{O}\right)$ & - & 178 & 31.00 & 31.21 & 14.32 & 14.49 & 4.47 & 4.11 \\
\hline $\mathrm{C}_{12} \mathrm{~N}_{8} \mathrm{H}_{28} \mathrm{Cl}_{2} \mathrm{O}_{3} \mathrm{~S}_{2} \mathrm{Pd}\left(2 \cdot 3 \mathrm{H}_{2} \mathrm{O}\right)$ & 205 & 155 & 24.84 & 25.11 & 19.68 & 19.51 & 4.43 & 4.87 \\
\hline $\mathrm{C}_{14} \mathrm{~N}_{8} \mathrm{H}_{34} \mathrm{Cl}_{2} \mathrm{O}_{4} \mathrm{~S}_{2} \mathrm{Pd}\left(3 \cdot 4 \mathrm{H}_{2} \mathrm{O}\right)$ & 201 & 143 & 26.72 & 27.11 & 17.84 & 18.13 & 5.32 & 5.46 \\
\hline $\mathrm{C}_{24} \mathrm{~N}_{8} \mathrm{H}_{40} \mathrm{Cl}_{2} \mathrm{O}_{5} \mathrm{~S}_{2} \mathrm{Pd}\left(4 \cdot 5 \mathrm{H}_{2} \mathrm{O}\right)$ & 194 & 146 & 37.62 & 37.80 & 14.43 & 14.71 & 5.51 & 5.33 \\
\hline $\mathrm{C}_{16} \mathrm{~N}_{8} \mathrm{H}_{42} \mathrm{Cl}_{2} \mathrm{O}_{5} \mathrm{~S}_{2} \mathrm{Pd}\left(\mathbf{5} \cdot 5 \mathrm{H}_{2} \mathrm{O}\right)$ & 199 & 138 & 28.64 & 28.91 & 17.01 & 16.78 & 5.79 & 6.08 \\
\hline $\mathrm{C}_{36} \mathrm{~N}_{8} \mathrm{H}_{44} \mathrm{Cl}_{2} \mathrm{O}_{3} \mathrm{~S}_{2} \mathrm{Pd}\left(\mathbf{6} \cdot 3 \mathrm{H}_{2} \mathrm{O}\right)$ & 192 & 117 & 53.10 & 53.44 & 9.78 & 10.11 & 5.74 & 5.92 \\
\hline
\end{tabular}

air-stable powders and exhibit a red brownish color. The molar conductivities of complexes 2-6 in methanol are between 185-214 $\Omega^{-1} \mathrm{~cm}^{2} \mathrm{~mol}^{-1}$ and is in agreement with their 1:2 electrolytic character. ${ }^{25}$ The low solubility of $\mathbf{1}$ in methanol (and other non-coordinating solvents) has precluded measurements of its molar conductivity. Analytical results are in agreement with their proposed formulae ( $\mathrm{Ta}-$ ble 1).

\section{1. IR and NMR Studies}

The neutral bidentate chelating coordination mode of $\mathrm{tmbiimH}_{2}$ was clearly evidenced in the IR spectrum of 1. Firstly, the presence of an intense $v \mathrm{~N}-\mathrm{H}$ absorption at $3227 \mathrm{~cm}^{-1}$ is indicative of the neutral character of the imidazolyl ligand. According to the literature, the shift of $v \mathrm{~N}-\mathrm{H}$ absorption to higher energies in the IR spectrum of 1 compared to the position found in that of the free tmbimH $_{2}\left(\sim 3000 \mathrm{~cm}^{-1}\right)$ is typical of neutral bidentate chelating coordination mode. ${ }^{26}$ Second, the decrease in intensity and shift to lower frequency of the band attributed to the $\nu \mathrm{C}=\mathrm{N}$ and in-plane $\mathrm{N}-\mathrm{H}$ bending mode $(\delta \mathrm{N}-\mathrm{H})$ in $\mathbf{1}$ $\left(1594 \mathrm{~cm}^{-1}\right)$, compared with that of the ligand $\left(1604 \mathrm{~cm}^{-1}\right)$, is also an evidence of the chelating coordination mode of tmbiimH $\mathrm{H}_{2}$. The presence of water of hydration was detected by the appearance of its characteristic absorptions at $3485 \mathrm{~cm}^{-1}(\mathrm{vO}-\mathrm{H})$ and $1660 \mathrm{~cm}^{-1}(\delta \mathrm{HOH})$.

IR spectra of compounds 2-6 exhibited a very broad continuum band over the spectral range of 3560-2500 $\mathrm{cm}^{-1}$ assigned to the vibrations of water molecules, counterions and coordinated ligands involved in hydrogen bonding interactions. It is important to point out that the expected $\nu \mathrm{C}=\mathrm{N}$ band of the neutral bidentate chelating tmbiim $\mathrm{H}_{2}$ ligand was observed in IR spectra of compounds 2 to 6 .

Among the physical techniques employed to evidence the coordination mode of thiourea-type ligands, IR spectroscopy is one of the most widely used method. ${ }^{27-30}$ The shift of $v \mathrm{CN}$ and $v \mathrm{CS}$ absorptions is frequently used as diagnosis for $S$-coordination. Firstly, the intense $v \mathrm{CN}$ absorption at $1475 \mathrm{~cm}^{-1}(\mathrm{tu}), 1556 \mathrm{~cm}^{-1}(\mathrm{mtu}), 1463 \mathrm{~cm}^{-1}$ (ptu), $1560 \mathrm{~cm}^{-1}$ (dmtu) and $1326 \mathrm{~cm}^{-1}$ (dptu) observable in the IR spectra of the ligands, ${ }^{30-35}$ decreased in intensity and shifted to $1504 \mathrm{~cm}^{-1}(2), 1576 \mathrm{~cm}^{-1}(3), 1448 \mathrm{~cm}^{-1}$ (4),
$1593 \mathrm{~cm}^{-1}$ (5) after coordination. In 6, the $v \mathrm{CN}$ shift has small displacement. Secondly, it was noticed a shift of the $v$ CS band to lower frequency [2 $\left(709 \mathrm{~cm}^{-1}\right), 3\left(767 \mathrm{~cm}^{-1}\right)$, $4\left(751 \mathrm{~cm}^{-1}\right), 5\left(718 \mathrm{~cm}^{-1}\right)$ and $\left.6\left(906 \mathrm{~cm}^{-1}\right)\right]$ when compared with that of the free ligands [tu $\left(730 \mathrm{~cm}^{-1}\right), \mathrm{mtu}(776$ $\left.\mathrm{cm}^{-1}\right)$, ptu $\left(811 \mathrm{~cm}^{-1}\right)$, dmtu $\left(725 \mathrm{~cm}^{-1}\right)$ and dptu $(933$ $\left.\left.\mathrm{cm}^{-1}\right)\right]^{30-35}$ These spectroscopic modifications clearly indicated an increase of the double bond character of the $\mathrm{CN}$ bond and a weakening of the $\mathrm{C}=\mathrm{S}$ bond, being consistent with $S$-bonding of thiourea-type ligands in 2-6. ${ }^{36}$

According to the literature, ${ }^{15}$ one singlet at $2.19 \mathrm{ppm}$ is observed in the ${ }^{1} \mathrm{H}$ NMR spectrum of the free $\mathrm{tmbiimH}_{2}$. The appearance of this single signal indicates that $\mathrm{Me}^{4,4^{\prime}}$ and $\mathrm{Me}^{5,5^{5}}$ must be magnetically equivalent, possibly due to the rapid migration of the nitrogen atom's protons. ${ }^{37}{ }^{1} \mathrm{H}$ NMR spectra of freshly prepared samples of 1, 2 and 3 showed the presence of one single peak at $c a .2 .20 \mathrm{ppm}$ (Table 2), which may indicate that the tmbiim $\mathrm{H}_{2}$ is totally dissociated in DMSO- $d_{6}$. This behavior has also been observed in other 2,2'-bisimidazolyl-based metal complexes in DMSO solutions. ${ }^{37}$

On the other hand, in the ${ }^{1} \mathrm{H}$ NMR spectrum of 4 , two singlet resonances of equal integrated area were observed at 2.23 and $1.19 \mathrm{ppm}$ and assigned to chemically inequivalent tmbiim $\mathrm{H}_{2}$ ring methyl groups $\left(\mathrm{Me}^{4,4^{\prime}}, \mathrm{Me}^{5,5^{5}}\right)$, in agreement with the bidentate chelating coordination mode of $\mathrm{tmbiimH}_{2}$ ligand. Over a period of time, these signals attributed to the mononuclear compound in solution decrease in intensity with the appearance and increase in intensity of one single peak at $2.19 \mathrm{ppm}$, suggesting that the dissociation rate of the tmbiimH $\mathrm{H}_{2}$ ligand in 4 , in DMSO- $d_{6}$, is relatively slower that observed for $\mathbf{1 - 3}$. This finding could be probably related to the expected decrease of the rate of substitution reactions in square planar complexes due to the presence of more sterically demanding $\mathrm{N}$-phenylthiourea ligands, increasing the difficulty encountered by the entering ligand in binding to the metal center during an associative substitution process. ${ }^{38}$

In 5, two signals groups were observed. The first group show one signal in $2.23 \mathrm{ppm}$, assigned to chemically equivalent $\mathrm{tmbiimH}_{2}$ ring methyl groups $\left(\mathrm{Me}^{4,4^{\prime}}, \mathrm{Me}^{5,5^{\prime}}\right)$ for free ligand in solution and two singlet resonances of equal integrated area in 2.11 and $1.20 \mathrm{ppm}$, assigned to chemically inequivalent tmbiim $\mathrm{H}_{2}$ ring methyl groups 
$\left(\mathrm{Me}^{4,4^{\prime}}, \mathrm{Me}^{5,5^{\prime}}\right)$ for coordinated ligand. The same manner as 4 , over a period of time, the signals attributed to the mononuclear compound in solution (2.11 and $1.20 \mathrm{ppm}$ ) decrease in intensity with the appearance and increase in intensity of one single peak at $2.23 \mathrm{ppm}$. The second group shows one signal in $3.43 \mathrm{ppm}$ and two signals in 3.67 and $3.65 \mathrm{ppm}$, assigned for methyl groups for coordinated $N, N^{\prime}$-dimethylthiourea ligand. ${ }^{39}$

The ${ }^{1} \mathrm{H}$ NMR spectrum of 6 were obtained in DMSO- $d_{6}$ solution and only one signal in $2.20 \mathrm{ppm}$ assigned to chemically equivalent $\mathrm{tmbiimH}_{2}$ ring methyl groups $\left(\mathrm{Me}^{4,4^{\prime}}, \mathrm{Me}^{5,5^{3}}\right)$ for free ligand in solution.

In short, when solubilized, all compounds showed a possible dynamic equilibrium between the partial exit of the coordinated ligands and the coordination of solvent molecules (such as $\mathrm{H}_{2} \mathrm{O}$, present in the composition of the compounds themselves, or the deuterated solvent itself). Even when spectra were obtained immediately after solubilization and with times oscillating between $1 \mathrm{~h}$ and $48 \mathrm{~h}$, these same behaviors were noticed, even when other deuterated solvents were used. However, due to the low resolution of the spectra obtained in other solvents, we chose to maintain the data presented in DMSO- $d_{6}$, since the compounds were appreciably more soluble in this solvent, compared to the other deuterated solvents used.

Electronic delocalisation in a copper-(1-phenylthiourea) complex, ${ }^{40}$ which has a thiourea-derivated ligand, as well as our compounds, also seems to corroborate us for a dynamics of exchange processes.

\section{2. Cytotoxic Activities Against Murine Tumor Cell Lines}

The cytotoxic activities of the palladium(II) complexes 1-6 were tested against murine mammary adenocarcinoma (LM3), lung adenocarcinoma (LP07) and mouse fibrosarcoma (L929) cell lines. Cells were exposed to a range of drug concentrations $\left(300-10 \mu \mathrm{mol} \mathrm{L}^{-1}\right)$ for 24 $\mathrm{h}$ and cell viability was analyzed by MTT assay. $\mathrm{IC}_{50}$ values (the concentration that inhibited in $50 \%$ the cellular proliferation) are presented in Table 3 . The cytotoxicity data of cisplatin against the selected tumor cell lines were used for comparison purposes. ${ }^{16,41}$

Compounds 1-6 showed no drug response at drug concentrations $<300 \mu \mathrm{mol} \mathrm{L}{ }^{-1}$ against LP07 cells, and thus they were considered inactive. After treatment of LM3 cells with compounds 1-6, it was observed that the replacement of two chlorido by two thiourea $(1 \rightarrow 2)$, two $N$-methylthiourea ligands $(\mathbf{1} \rightarrow \mathbf{3})$ or two $N, N$ '-methylthiourea ligands $(\mathbf{1} \rightarrow \mathbf{5})$ did not result in any increase in the cytotoxic activity towards LM3 cell line. On the other hand, 4 , containing the sterically demanding $\mathrm{N}$-phenylthiourea ligand, was $c a .2$ fold more active than compounds 1-3 and 5, and approximately 4 times less active than cis-

Table 2. ${ }^{1} \mathrm{H}-\mathrm{NMR}$ chemical shift (ppm) for the compounds at $298 \mathrm{~K}$.

\begin{tabular}{|c|c|c|c|}
\hline Compound & $M e^{4,4^{\prime}} / M^{5,5^{\prime}}$ & $\begin{array}{l}{ }^{1} \mathrm{H} \text { NMR data } \\
N \text {-derivative thiourea group }(\mathrm{R})\end{array}$ & Numbering scheme \\
\hline 1 & $2.20(s, 12 \mathrm{H})$ & - & \\
\hline 2 & $2.23(s, 12 \mathrm{H})$ & - & \\
\hline 3 & $2.19(s, 12 \mathrm{H})$ & $2.78(s, 6 \mathrm{H})$ & \\
\hline 4 & $\begin{array}{l}2.23(s, 6 \mathrm{H}) \\
1.19(s, 6 \mathrm{H})\end{array}$ & $7.80-7.20(b r, 10 \mathrm{H})$ & \\
\hline 5 & $\begin{array}{l}2.11(s, 6 \mathrm{H}) \\
1.20(s, 6 \mathrm{H})\end{array}$ & $\begin{array}{l}3.67(s, 6 \mathrm{H}) \\
3.65(s, 6 \mathrm{H})\end{array}$ & $\mathrm{HN}$ \\
\hline 6 & $2.20(s, 12 \mathrm{H})$ & $7.60-6.90(b r, 20 \mathrm{H})$ & \\
\hline
\end{tabular}

Abbrevations: $s=$ singlet; $b r=$ broadned; $\mathrm{R}=\mathrm{H}(2), \mathrm{Me}(3)$, and $\mathrm{Ph}(4) ; \mathrm{R}=\mathrm{R}^{\prime}=\mathrm{Me}(5)$, and $\mathrm{Ph}(6)$.

Deuterated solvent employed: DMSO- $d_{6}$ (for 1-6). NH signals could not be observed.

Table 3. Cytotoxicity $\left(\mathrm{IC}_{50}\right)$ of the coordination compounds 1-6 and cisplatin against murine LM3, L929 and LP07 cell lines.

\begin{tabular}{|c|c|c|c|c|}
\hline \multirow[t]{2}{*}{ Compound } & \multicolumn{3}{|c|}{$\mathrm{IC}_{50}\left(\mu \mathrm{mol} \mathrm{L}{ }^{-1}\right)$} & \multirow[t]{2}{*}{ Reference } \\
\hline & LM3 & L929 & LP07 & \\
\hline 1 & $289.6 \pm 1.9$ & Inactive & Inactive & This work \\
\hline 2 & $278.2 \pm 1.3$ & $241.9 \pm 1.1$ & Inactive & This work \\
\hline 3 & $260.9 \pm 1.1$ & $88.1 \pm 0.4$ & Inactive & This work \\
\hline 4 & $109.5 \pm 0.9$ & $30.7 \pm 0.2$ & Inactive & This work \\
\hline 5 & $255.4 \pm 1.7$ & $40.9 \pm 0.2$ & Inactive & This work \\
\hline 6 & $8.9 \pm 0.3$ & $7.3 \pm 0.1$ & Inactive & This work \\
\hline Cisplatin & $30.6 \pm 3.7$ & $65.3 \pm 1.9$ & $4.34 \pm 0.4$ & 16,41 \\
\hline
\end{tabular}

Franchi et al.: Synthesis, Characterization and Cytotoxicity Evaluation ... 
platin. The compound 6 showed drug response at drug concentrations $8.9 \mu \mathrm{mol} \mathrm{L}^{-1}$, approximately 3 times more active than cisplatin. In this case, the presence to more sterically ligand ( $N, N^{\prime}$-diphenylthiourea) increases cytotoxic activity against this cell line.

With respect to the cytotoxic effects on L929 cells, a progressive increase on the cytotoxic activity of $\mathrm{Pd}(\mathrm{II})$ complexes was noticed according to the ancillary ligand bulkiness of substituents on thiourea moiety, following the order $\mathrm{tu}<\mathrm{mtu}<\mathrm{dmtu}<\mathrm{ptu}<\mathrm{dptu}$. Probably, a lipophilic effect is prevalent for this series of compounds when $\mathrm{H}$ atoms are substituted by methyl and phenyl groups. Compound $\mathbf{6}$ not only showed the highest cytotoxic activity against $\mathrm{L} 929$ cell line $\left(\mathrm{IC}_{50}\right.$ value of $7.3 \mu \mathrm{mol} \mathrm{L}^{-1}$ ) among all tested compounds, but also it was more active than cisplatin $\left(65.3 \mu \mathrm{mol} \mathrm{L}^{-1}\right){ }^{41}$

Our findings agree well with those described by Marverti and co-workers, ${ }^{8}$ in which it was verified that the cytotoxicity of the metallointercalators $\left[\mathrm{Pt}(\mathrm{bpy}) \mathrm{L}_{2}\right] \mathrm{Cl}_{2}$ (bpy $=2,2^{\prime}$-bipyridine; $\mathrm{L}=$ thioureas) was dependent on the structure of thiourea substituents.

\section{Conclusions}

The synthesis, structural and spectroscopic characterization, as well as the biological activity of palladium(II) compounds containing 2,2'-bis(4,5-dimethylimidazole) and thiourea-type ligands were described in this work. Conductivity data in methanol were in agreement with a 1:2 electrolyte nature for compounds $\mathbf{2 - 6}$. The IR data of 1-6 were consistent with the presence of chelating tmbiimH $\mathrm{H}_{2}$ ligand and $S$-coordination of thioureas. NMR studies on compounds 1-3 and $\mathbf{6}$ in DMSO- $d_{6}$ indicated that $\mathrm{tmbiimH}_{2}$ ligand is completely dissociated. On contrary, the dissociation rate of the $\mathrm{tmbiimH}_{2}$ in $\mathbf{4}$ and $\mathbf{5}$ is slower than that observed for 1-3. The distinct behavior of 4 in solution may be responsible for the maintenance of its structural integrity long enough to reach the pharmacological targets as well as for its highest cytotoxicity against LM3 and L929 cell lines, when compared to compounds $\mathbf{1 - 3}$. The substituent groups in thiourea-type ligands are directly related to the increase in citotoxicity.

The good cytotoxicity presented by compound 6 deserves considerable attention, which presents us the challenge of finding better conditions of stability for it in solution, either by drug delivery systems or structural modifications to fulfill with greater success its action in the pharmacological targets.

\section{Acknowledgements}

This research was supported by FAPESP, CNPq and Capes (Brazilian agencies of research).

\section{References}

1. L. Kelland, Nat. Rev. Cancer 2007, 7, 573-584. DOI: $10.1038 / \mathrm{nrc} 2167$

2. D. Wang, S. J. Lippard, Nat. Rev. Drug Discov. 2005, 4, 307320. https://www.nature.com/articles/nrd1691

3. F. Arnesano, G. Natile, Coord. Chem. Rev. 2009, 253, 20702081. DOI:10.1016/j.ccr.2009.01.028

4. S. H. van Rijt, P. J. Sadler, Drug Discov. Today 2009, 14, 10891097. DOI:10.1016/j.drudis.2009.09.003

5. B. Lippert, Coord. Chem. Rev. 1999, 182, 263-295. DOI:10.1016/S0010-8545(98)00192-1

6. G. Momekov, A. Bakalova, M. Karaivanova, Curr. Med. Chem. 2005, 12, 2177-2191. DOI:10.2174/0929867054864877

7. M. J. Hannon, Chem. Soc. Rev. 2007, 36, 280-295. DOI:10.1039/b606046n

A. Mushtaq, S. Ali, M. N. Tahir, H. Ismail, B. Mirza, M. Saadiq, M. A. Haleem, M. Iqbal, Acta Chim. Slov. 2017, 64, 397-408. DOI:10.17344/acsi.2017.3250

S.Tsiliou, L.-A. Kefala, A. G. Hatzidimitriou, D. P. Kessissoglou, F. Perdih, A. N. Papadopoulos, I. Turel, G. Psomas, J. Inorg. Chem. 2016, 160, 125-139.

DOI:10.1016/j.jinorgbio.2015.12.015

E. P. Irgi, G. D. Geromichalos, S. Balala, J. Kljun, S. Kalogiannis, A. Papadopoulos, I. Turel, G. Psomas, RSC Adv. 2015, 5, 36353-36367. DOI:10.1039/C5RA05308K

8. G. Marverti, M. Cusumano, A. Ligabue, M. L. Pietro, P. A. Vainiglia, A. Ferrari, M. Bergomi, M. S. Moruzzi, C. Frassineti, J. Inorg. Biochem. 2008, 102, 699-712.

DOI:10.1016/j.jinorgbio.2007.10.015

9. M. Cusumano, M. L. Di Pietro, A. Giannetto, P. A. Vainiglia, J. Inorg. Biochem. 2005, 99, 560-565.

DOI:10.1016/j.jinorgbio.2004.11.002

10. A. Rotondo, S. Barresi, M. Cusumano, E. Rotondo, Polyhedron 2012, 45, 23-29. DOI:10.1016/j.poly.2012.07.064

11. M. A. M. Lorente, F. Dahan, Y. Sanakis, V. Petrouleas, A. Bousseksou, J. P. Tuchagues, Inorg. Chem. 1995, 34, 53465357. DOI:10.1021/ic00125a039

12. I. G. Dance, A. S. Abushamleh, H. A. Goodwin, Inorg. Chim. Acta 1980, 43, 217-221.

DOI:10.1016/S0020-1693(00)90532-2

13. R. Indumathy, T. Weyhermuller, B. U. Nair, Dalton Trans. 2010, 39, 2087-2097. DOI:10.1039/b913464f

14. K. Kurdzeil, Solvent Extr. Ion Exc. 1994, 12, 687-699. DOI:10.1080/07366299408918232

15. T. W. Stringfield, K. V. Somayajula, D. C. Muddiman, J. W. Flora, R. E. Shepherd, Inorg. Chim. Acta 2003, 343, 317-328. DOI:10.1016/S0020-1693(02)01243-4

16. R. A. de Souza, A. Stevanato, O. Treu-Filho, A. V. G. Netto, A. E. Mauro, E. E. Castellano, I. Z. Carlos, F. R. Pavan, C. Q. F. Leite, Eur. J. Med. Chem. 2010, 45, 4863-4868.

DOI:10.1016/j.ejmech.2010.07.057

17. F. V. Rocha, C. V. Barra, A. V. G. Netto, A. E. Mauro, I. Z. Carlos, R. C. G. Frem, S. R. Ananias, M. B. Quilles, A. Stevanato, M. C. da Rocha, Eur. J. Med. Chem. 2011, 45, 1698-1702.

DOI:10.1016/j.ejmech.2009.12.073 
18. R. A. de Souza, A. E. Mauro, A. V. G. Netto, G. A. Cunha, E. T. de Almeida, J. Therm. Anal. Calorim. 2011, 106, 375-378. DOI:10.1007/s10973-010-1216-8

19. A. C. Moro, G. A. da Silva, R. F. F. de Souza, A. E. Mauro, A. V. G. Netto, I. Z. Carlos, F. A. Resende, E. A. Varanda, F. R. Pavan, C.Q. F. Leite, Med. Chem. Res. 2015, 24, 2879-2888. DOI:10.1007/s00044-015-1339-3

20. A. M. A. Velásquez, R. A. de Souza, T. G. Passalacqua, A. R. Ribeiro, M. Scontri, C. M. Chin, L. Almeida, M. L. Del Cistia, J. A. da Rosa, A. E. Mauro, M. A. S. Graminha, J. Braz. Chem. Soc. 2016, 27, 1032-1039. DOI: $10.5935 / 0103-5053.20150360$

21. A. M. A. Velásquez, W. C. Ribeiro, V. Venn, S. Castelli, M. S. Camargo, R. P. de Assis, R. A. de Souza, A. R. Ribeiro, T. G. Passalacqua, J. A. da Rosa, A. M. Baviera, A. E. Mauro, A. Desideri, E. E. Almeida-Amaral, M. A. S. Graminha, Antimicrob. Agents Chemother. 2017, 61, e00688-17.

DOI:10.1128/AAC.00688-17

22. P. Chattopadhyay, M. K. Nayak, S. P. Bhattacharya, C. Sinha, Polyhedron 1997, 16, 1291-1295.

DOI:10.1016/S0277-5387(96)00422-6

23. J. S. Casas, A. Castineiras, Y. Parajó, M. L. Pérez-Parallé, A. Sánchez, A. Sánchez-González, J. Sordo, Polyhedron, 2003, 22, 1113-1121. DOI:10.1016/S0277-5387(03)00097-4

24. T. Mosmann, J. Immunol. Methods 1983, 65, 55-63. DOI:10.1016/0022-1759(83)90303-4

25. W. J. Geary, Coord. Chem. Rev. 1971, 7, 81-122. DOI:10.1016/S0010-8545(00)80009-0

26. C. Kirchner, B. Krebs, Inorg Chem, 1987, 26, 3569-3576. DOI:10.1021/ic00268a030

27. D. Gambino, L. Otero, E. Kremer, O. E. Piro, E. E. Castellano, Polyhedron, 1997, 16, 2263-2270. DOI:10.1016/S0277-5387(96)00534-7

28. G. M. S. El-Bahy, B. A. El-Sayed, A. A. Shabana, Vib. Spectrosc. 2003, 31, 101-107. DOI:10.1016/S0924-2031(02)00099-1
29. S. Ahmad, A. A. Isab, S. Ahmad, J. Coord. Chem. 2003, 56, 1587-1595. DOI:10.1080/00958970310001641688

30. S. Nadeem, M. K. Rauf, M. Bolte, S. Ahmad, S. A. Tirmizi, M. Asma, A. Hameed, Transition Met. Chem. 2010, 35, 555-561. DOI:10.1007/s11243-010-9363-0

31. L. Bencivenni, S. N. Cesaro, A. Pieretti, Vib. Spectrosc. 1998, 18, 91-102. DOI:10.1016/S0924-2031(98)00039-3

32. Y. Mido, I. Kitagawa, M. Hashimoto, H. Matsuura, Spectrochim. Acta A 1999, 55, 2623-2633.

DOI:10.1016/S1386-1425(99)00062-1

33. H. M. Badawi, Spectrochim Acta A 2009, 72, 523-527. DOI:10.1016/j.saa.2008.10.042

34. K. R. G. Devi, D. N. Sathyanarayana, Bull. Chem. Soc. Jpn. 1980, 53, 2990-2994. DOI:10.1246/bcsj.53.2990

35. C. Y. Panicker, H. T. Varghese, A. George, P. K. V. Thomas, Eur. J. Chem. 2010, 1, 173-178.

DOI:10.5155/eurjchem.1.3.173-178.42

36. L. Fuks, N. Sadlej-Sosnowska, K. Samochocka, W. Starosta, J. Mol. Struct. 2005, 740, 229-235.

DOI:10.1016/j.molstruc.2005.01.008

37. A. S. González, J. S. Casas, J. Sordo, U. Russo, M. I. Lareo, B. J. Regueiro, J. Inorg. Biochem. 1990, 39, 227-235.

DOI:10.1016/0162-0134(90)84006-B

38. J. Berger, M. Kotowski, R. van Eldik, U. Frey, L. Helm, A. E. Merbach, Inorg. Chem. 1989, 28, 3759-3765.

DOI:10.1021/ic00318a028

39. Y. Mido, H. Mizuno, T. Suzuki, T. Okuno, Spectrochim. Acta A 1986, 42, 807-809. DOI:10.1016/0584-8539(86)80108-8

40. Y. Liu, D. -J. Xu, Acta. Cryst. 2004, E60, m1057-m1059. DOI:10.1107/S160053680401582X

41. V. M. Leovac, G. A. Bogdanović, L. S. Jovanović, L. Joksović, V. Marković, M. D. Joksović, S. M. Denčić, A. Isaković, I. Marković, F. W. Heinemann, S. Trifunović, I. Đalović, J. Inorg. Biochem. 2011, 105, 1413-1421.

DOI:10.1016/j.jinorgbio.2011.07.021

\section{Povzetek}

$\mathrm{Z}$ reakcijami med $\left[\mathrm{PdCl}_{2}\left(\mathrm{tmbiimH}_{2}\right)\right] \cdot \mathrm{H}_{2} \mathrm{O}(\mathbf{1})\left\{\mathrm{tmbiimH}_{2}=2,2^{\prime}\right.$-bis $(4,5$-dimetilimidazol $\left.)\right\}$ in tioureo (tu), $N$-metiltioureo (mtu), $N$-feniltioureo (ptu), $N, N^{\prime}$-dimetiltioureo (dmtu) oziroma $N, N^{\prime}$-difeniltioureo (dptu) v 1:2 molskem razmerju smo izolirali spojine $\left[\mathrm{PdL}_{2}\left(\mathrm{tmbiimH}_{2}\right)\right] \mathrm{Cl}_{2} \cdot \mathrm{nH}_{2} \mathrm{O}\{\mathrm{L}=\mathrm{tu}(2), \mathrm{mtu}(3), \mathrm{ptu}(4), \mathrm{dmtu}(5)$ and dptu (6)\}, ki smo jih okarakterizirali z elementno analizo, infrardečo (IR) in ${ }^{1} \mathrm{H}$ NMR spektroskopijo in merjenjem prevodnosti. IR spektri spojin 1-6 kažejo, da je v kompleksih prisoten kelatni tmbim $\mathrm{H}_{2}$ ligand. Vse pripravljene spojine in cisplatin smo testirali in vitro z MTT testom njihove citotoksičnosti na treh mišjih rakavih celičnih linijah: mišji adenokarcinom dojke (LM3), mišji pljučni adenokarcinom (LP07) in mišji fibroblasti (L929). Na podlagi primerjave biološke aktivnosti spojin, se izkazuje spojine 6 kot najobetavnejša. 